\title{
Prevalence and variety of sutural bones in densely populated East Indian state of Bihar
}

\section{Częstość występowania i różnorodność kostek szwów czaszki w gęsto zaludnionym stanie Bihar Indii Wschodnich}

\author{
Ravi Kant Narayan ${ }^{1}$ (D), Sarita Kumari², Manika Verma² \\ ${ }^{1}$ All India Institute of Medical Sciences, Patna, Bihar, India \\ ${ }^{2}$ Rajiv Gandhi Cancer Institute and Research Centre, New Delhi, India
}

\begin{abstract}
INTRODUCTION: Sutural bones or intersutural bones commonly known as Wormian bones are extra bone pieces that occur commonly within the sutures or at the fontanelles of the cranium.

MATERIAL AND METHODS: The present study was conducted at the All India Institute of Medical Sciences, Patna. Thirty complete, dry adult human skulls were studied and examined for the presence or absence of sutural bones. Their number and the location along the cranial sutures and at the fontanelles were noted. To take cranial measurements for the cranial index, the skulls were oriented on a Frankfurt plane.

RESULTS: The most common site where sutural bones were observed was at the lambdoid suture with the incidence of $61.2 \%$ of the sutural bones, while the second most common site was at the coronal sutures with $10.6 \%$ of the total sutural bones found. The dominant shape of the head in the present study population was dolichocephalic, observed in $46.6 \%$. The mean number of sutural bones was found to be highest in the most common skull type (dolichocephalic) with values of $5.43 \pm 5.1$.

CONCLUSIONS: Though the current study reports fewer sutural bones than in previous literature, given the high population density of the East Indian states, these presented mean values require special attention.
\end{abstract}

\section{KEY WORDS}

Wormian bones, cranial sutures, fontanelles, dolichocephalic

\section{STRESZCZENIE}

WSTĘP: Kostki szwów (kości wstawne lub śródszwowe), zwane kośćmi Worma, często występują w obrębie szwów lub ciemiączek czaszki, w obrębie desmocranium.

MATERIAŁ I METODY: Badania przeprowadzono w Instytucie Nauk Medycznych w Patnie w Indiach. Zbadano 30 wysuszonych ludzkich dorosłych czaszek w celu stwierdzenia występowania lub braku kostek szwów. Określono ich liczbę oraz lokalizację w obrębie szwów i ciemiączek. Pomiarów czaszek dokonano w płaszczyźnie frankfurckiej (tj. płaszczyźnie poziomej przechodzącej przez dolny brzeg oczodołu i górny brzeg otworu słuchowego).

WYNIKI: Najczęstszą lokalizacją kości szwów był szew węgłowy (sutura lambdoidea) - w 61,2\% badanych czaszek, oraz szew wieńcowy (sutura coronalis) - w 10,6\% badanych czaszek. Dominujący był typ długogłowy (długoczaszkowy - dolichocephalic, dolichocranium), występujący w 46,6\% badanych czaszek. Srednia liczba kości szwów była największa w typie dolichocefalicznym $-5,43 \pm 5,1$.

Received: 27.11.2018 Revised: 27.04.2019 Accepted: 05.05.2019 Published online: 17.09 .2019

Address for correspondence: Dr. Ravi Kant Narayan, Senior resident, Department of Anatomy, All India Institute of Medical Sciences, Patna, Bihar 801507 , India, tel. + 91923489 6343, e-mail: ravi.narayan@aiimspatna.org

Copyright $\odot$ Śląski Uniwersytet Medyczny w Katowicach www.annales.sum.edu.pl 
WNIOSKI: Obecne badania dotyczące kości szwów są niewielkie w porównaniu z badaniami we wcześniejszych publikacjach. Ze względu na dużą gęstość zaludnienia wschodnich stanów Indii prezentowane wyniki zasługują na uwagę.

\section{SŁOWA KLUCZOWE}

kostki Worma, szwy czaszki, ciemiączka, długogłowie

\section{INTRODUCTION}

Sutural bones or intersutural bones commonly known as Wormian bones are extra bone pieces that occur commonly within the sutures or at fontanelles of cranium. These bones are also called Schaltknochen, supernumerary ossicles, intercalary bones or Inca bones/ /Goethe's ossicle (Fig. 1b). They were first described by Paracelsus (1460 to 1541), a Swiss physician, alchemist, and astrologer of the German renaissance, who was credited as the "father of toxicology". The term Ossa Wormiana was given by Thomas Bartholin in honour

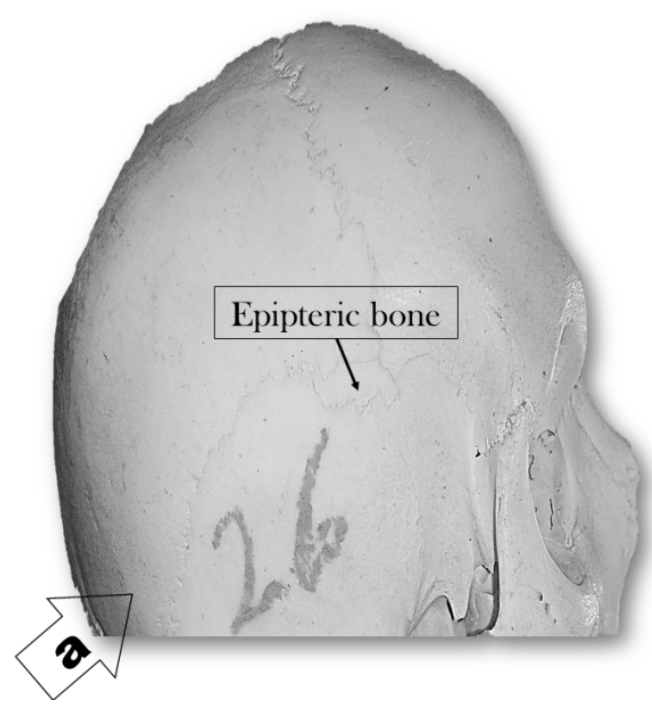

of the Danish anatomist, Olaus Worm, who described them in a letter from 1643 A.D. Although unusual, they are not infrequent bones and appear with the ir own ossification centres, different from normal ones [1]. They are also being named according to their topographical location such as bregmatic bone, sagittal ossicle and Inca bone at the lambda, all of which are seen in the midline, and pterion ossicles, epipteric bone (Fig. 1a) or Flower's bone at the pterion, squamous suture ossicles (Fig. 2c), ossicle at the asterion, occipitomastoid bone, the lambdoid ossicles are seen bilaterally in the cranium [2].

Fig. 1. Sutural bones at fontanelles: $a$ - epipteric bone at pterion; $b$ - Inca bone at lambda.

Ryc. 1. Kości wstawne w sklepieniu czaszki: a - z przodu w punkcie ciemiączka klinowego; b - kość Inków w punkcie ciemiączka tylnego.
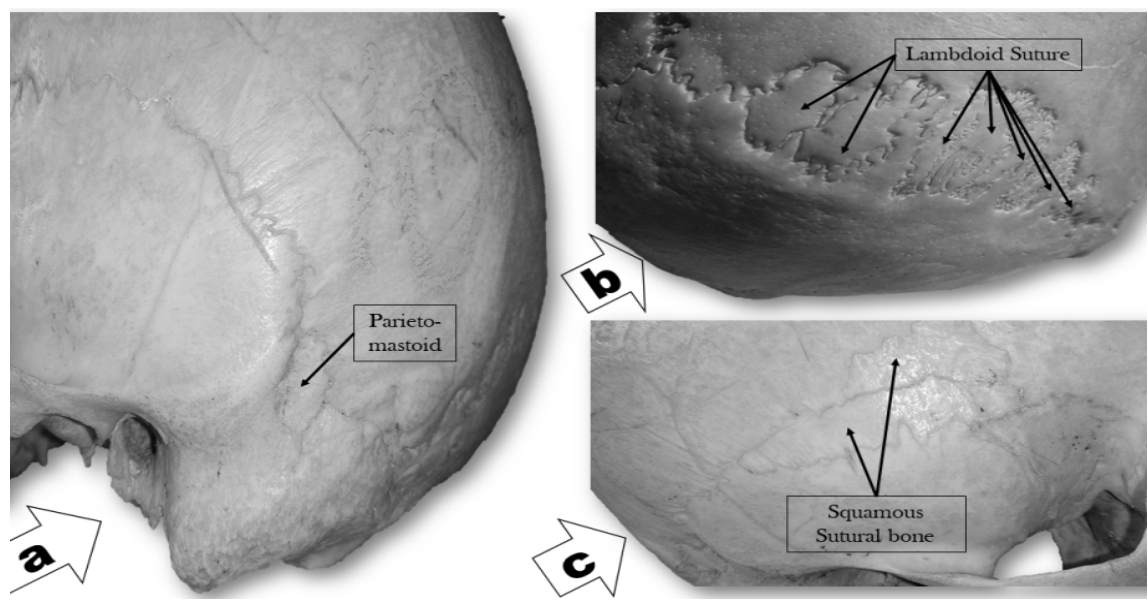

Fig. 2. Sutural bones at: a - parietomastoid ossicle (PM); b - lambdoid sutures (LS); $c$ - squamous sutural bone (SqS).

Ryc. 2. Kości wstawne w: a - wyrostku ciemieniowo-sutkowym (PM); b - szwach wegłowych (LS); c - łusce kości wstawnej (SqS). 
Among the myriad of factors explaining the existence of sutural bones, the most reasonable hypotheses suggest that the formation of sutural bones can be attributed to stress due to artificial cranial deformation as explained by Ogle et al. [3] or can also be a response to adaptation to enlargement of the cranium as per the hypotheses of Jeanty et al. [4], who also suggested that sutural diastasis induces the formation of ectopic ossification centres. Barberini et al. [5] proposed that the formation and distribution of intercalary bones may reflect different stress types (tension, pressure, etc.), acting on the cranial vault during late prenatal and early postnatal periods of bone growth. Hess attributed their formation to metabolic disorders of the mesoderm, as was also later observed in osteogenesis imperfecta, rickets, Menkes syndrome, cleidocranial dysostosis, hypothyroidism, otopalatodigital syndrome, primary acroosteolysis (Hajdu-Cheney Syndrome) and Down syndrome [6]. Wormian bones were considered intrinsically innocuous minor skeletal variants of the human skull by Hauser and De Stefano; they explained them to be an epigenetic trait to emphasize their possible modification during ontogeny [7]. The term epigenetic trait differentiates these features from "Mendelian traits" as they are not determined by a direct gene-character relationship and are completely independent of the environment. According to Grüneberg [8], their formation might be under the control of a number of genes with additive action (polygenic complex) and their phenotypic expression is conditioned by developmental thresholds

Some of the previous studies have shown that the presence of sutural bones may act as an indicator of central nervous system anomalies. Kaplan et al. [9] observed that the number and size of sutural bones are smaller in normal subjects as compared with those having skeletal dysplasias. Pryles and Khan [10] reported the prevalence of central nervous system abnormalities in a population with Wormian bones varies from 93\% to $100 \%$ in a random group and reaches $100 \%$ in a mentally retarded population.

These unusual sutural bones can be misdiagnosed as a fracture of skull bones or their presence can lead to difficulties in the posterior approach to the skull if they are in a series or they can complicate the burr hole procedure at the pterion. The anatomical landmarks of the bregma, lambda are associated with the superior sagittal sinus, while that of the asterion with the sigmoid sinus and the anterior division of the middle meningeal vessels are seen with pterion and all of them can produce profuse haemorrhage while trephining for neurosurgical procedures. Previous literature regarding the phylogeny and the occurrence of sutural bones within cranial sutures and at their meeting point lacks in data of the East Indian population, which is being put forth in this study and also compared with the data for different populations of world and India to further strengthen the knowledge of surgeons. Furthermore, the relation of sutural bones, if any with a particular cranial shape (based on the cranial index) was studied in the East Indian population of Bihar.

\section{MATERIAL AND METHODS}

The present study was conducted at the All India Institute of Medical Sciences, Patna. Thirty complete, dry adult human skulls were studied and examined for the presence or absence of sutural bones. Their number and the location along the cranial sutures such as the parietomastoid (PM) suture, lambdoid suture (LS), occipitomastoid suture (OM), coronal suture (CS), sagittal suture (SS), squamous suture (SqS) and at the fontanelles such as the bregma, lambda, pterion and at the asterion were noted. To take cranial measurements for the cranial index, the skulls were oriented on a Frankfurt plane. The measurements were taken using a digital Vernier calliper. The findings were tabulated and statistically analysed using the SPSS 20.0 program.

The following measurements were taken:

1) maximum cranial length: from the glabella to opisthocranion (posteriormost point in the midsagittal plane of the occiput) [11],

2) maximum cranial breadth: between two euryons (most lateral point on the side of the head) [11].

The cranial index was calculated using the following formula:

cranial index $(\mathrm{CI})=($ maximum cranial breadth $\div$ maximum cranial length $) * 100$

The head shapes were then classified according to the Garson [12] classification into the following categories (Table I).

\begin{tabular}{|c|c|}
\hline Head shape & Cranial index range \\
\hline Hyperdolichocephalic & $65-69.9$ \\
\hline Dolichocephalic & $70-74.9$ \\
\hline Mesaticephalic & $75-79.9$ \\
\hline Brachycephalic & $80-84.9$ \\
\hline
\end{tabular}

\section{RESULTS}

Out of the 30 studied skulls, $43 \%$ (13) of them were observed to have sutural bones at different loci of the cranium, while the majority of $67 \%$ (17) were devoid of the same. Of the $43 \%$ which possessed a sutural bone, $10 \%$ (3) had it on the left and $20 \%$ (6) had the same on the right side of the cranium while $13 \%$ (4) had them bilaterally, as shown in Table II.

\begin{tabular}{lc}
\multicolumn{2}{l}{ Table II. Incidence of skulls with sutural bones $(\mathrm{N}=30)$} \\
\begin{tabular}{l} 
Tabela II. Występowanie czaszek $\mathrm{z}$ kośćmi wstawnymi $(\mathrm{N}=30)$ \\
\hline Number of skulls with sutural bones
\end{tabular} \\
\hline Present & $13(43 \%)$ \\
Absent & $17(67 \%)$ \\
Left half & $3(10 \%)$ \\
Right half & $6(20 \%)$ \\
Both sides & $4(13 \%)$
\end{tabular}




\section{Distributional incidence of sutural bones at different cranium loci}

The most common site where sutural bones were observed was at the lambdoid suture with the incidence of $61.2 \%$ of the sutural bones located there; out of this most were seen on the right side $(44.23 \%)$, while $36.5 \%$ were on the left side and $19.23 \%$ were bilaterally observed (as shown in Fig. 3a, Table III). The next loci with a higher incidence of sutural bones was at the coronal sutures with $10.6 \%$ of the total observed sutural bones, this comprised of $44.4 \%$ of the bilateral pres- ence followed by $33.3 \%$ of the unilateral presence on the right and $22.2 \%$ on the left side in different crania respectively. Therefore, the presence of sutural bones at the lambda was $8.2 \%$ in the midline, at the pterion it was $7.05 \%$ and at the occipitomastoid suture it was $5.88 \%$; notably all the sutural bones at the latter two positions were unilaterally observed as depicted in a few examples in Fig. 4a, 4b. Loci such as the asterion (Fig. 4b), parietomastoid suture and squamous suture (Fig. 2a, 2c) were observed to have the same incidence of sutural bones with a value of $2.35 \%$ for each, and at the bregma and sagittal suture there were none.
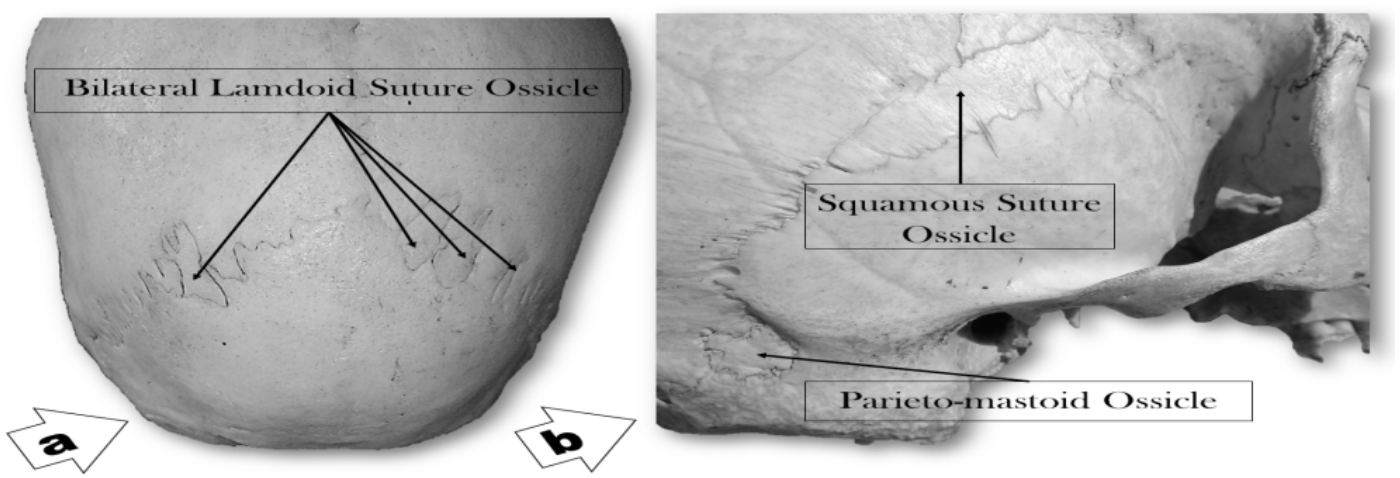

Fig. 3. a - posterior aspect of skull showing bilateral distribution of sutural bones at lambdoid suture; $b$ - lateral aspect of skull showing squamous suture ossicle with parietomastoid ossicle (PM).

Ryc. 3. a - projekcja tylna czaszki ukazująca obustronny rozkład kości wstawnych w szwie węgłowym; b - projekcja boczna czaszki z kością wstawną i wyrostkiem ciemieniowo-sutkowym (PM).

Table III. Incidence of sutural bones at different locations of cranium Tabela III. Występowanie kości wstawnych w różnych miejscach czaszki

\begin{tabular}{|c|c|c|c|c|c|}
\hline Locations & Right (U/L) & Left (U/L) & Midline & Bilateral & Total (\%) \\
\hline Bregma & Nil & Nil & Nil & Nil & 0 \\
\hline Lambda & Nil & Nil & 7 & Nil & $7(8.2 \%)$ \\
\hline Pterion & 2 & 4 & Nil & Nil & $6(7.05 \%)$ \\
\hline Asterion & Nil & Nil & Nil & $2(1 * 2=2)$ & $2(2.35 \%)$ \\
\hline Parietomastoid (PM) & 1 & 1 & Nil & Nil & $2(2.35 \%)$ \\
\hline Lambdoid suture (LS) & 23 & 19 & Nil & $\begin{array}{l}4\left(1^{*} 4=4\right) ; \\
6\left(3^{*} 2=6\right)\end{array}$ & $52(61.2 \%)$ \\
\hline Occipitomastoid suture (OM) & 2 & 3 & Nil & Nil & $5(5.88 \%)$ \\
\hline Coronal suture (CS) & 3 & 2 & Nil & $4\left(2^{\star} 2=4\right)$ & $9(10.6 \%)$ \\
\hline Sagittal suture (SS) & Nil & Nil & Nil & Nil & 0 \\
\hline Squamous suture (SqS) & 2 & Nil & Nil & Nil & $2(2.35 \%)$ \\
\hline
\end{tabular}



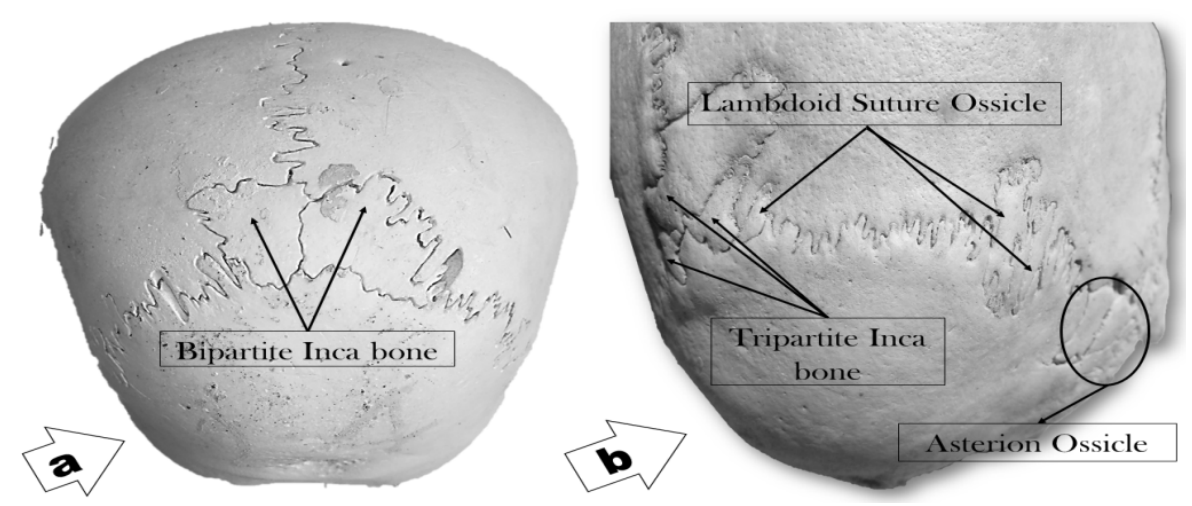

Fig. 4. a - posterior aspect of skull showing bipartite Inca bone at lambda; b - posterolateral aspect of skull showing tripartite Inca bone, lambdoid suture ossicle and sutural bone at asterion.

Ryc. 4. a - tylna projekcja czaszki z dwuczęściową kością w szwie węgłowym; b - tylno-boczna projekcja czaszki ukazująca trójczłonową kość Inków, kostkę wstawną w szwie węglowym w punkcie asterion.

Table IV shows that out of 13 skulls presenting sutural bones, 20\% (6) had 2 ossicles each, 16.6\% (5) had more than 5 ossicles each, 13\% (4) had single sutural bones, while $10 \%$ (3) had three ossicles each, respectively.

\section{Prevalence of different skull shapes and incidence of sutural bones in them}

In the present study population of East India, the predominant skull type on the basis of the cranial index was observed to be dolichocephalic with a prevalence of $46.6 \%$, followed by hyperdolichocephalic (30\%), mesaticephalic $(16.6 \%)$ and brachycephalic $(6.6 \%)$, respectively.

The mean number of sutural bones was found to the highest in the most common skull type, dolichocephalic, with values of $5.43 \pm 5.1$, which were present in 7 out of 14 dolichocephalic skulls. The minimum mean value of $1.5 \pm 0.5$ sutural bones was observed in each of the 2 brachycephalic type of skulls found, as shown in Table V. Four of the 9 hyperdolichocephalic skulls had $4.75 \pm 1.47$ sutural bones each and 3 of the mesaticephalic had a mean value of $4.33 \pm 2.67$ for each.

\begin{tabular}{lc}
\multicolumn{3}{l}{ Table IV. Number of sutural bones in skulls } \\
Tabela IV. Liczba kości wstawnych w czaszce \\
\hline Number of sutural bones & Number of skulls \\
\hline 0 & $17(67 \%)$ \\
1 & $4(13 \%)$ \\
2 & $6(20 \%)$ \\
3 & $3(10 \%)$ \\
4 & 0 \\
5 & 0 \\
$>5$ & $5(16.6 \%)$ \\
\hline
\end{tabular}

\begin{tabular}{|c|c|c|c|c|}
\hline \multirow{2}{*}{ Head shape } & \multirow{2}{*}{$\begin{array}{c}\text { Number of skulls belonging } \\
\text { to each shape }(\%)\end{array}$} & \multicolumn{2}{|c|}{ Number of skulls with sutural bones } & \multirow{2}{*}{$\begin{array}{c}\text { Mean number of sutural } \\
\text { bones } \pm \text { SD }\end{array}$} \\
\hline & & present & absent & \\
\hline Hyperdolichocephalic & $9(30 \%)$ & 4 & 5 & $4.75 \pm 1.47$ \\
\hline Dolichocephalic & $14(46.6 \%)$ & 7 & 7 & $5.43 \pm 5.1$ \\
\hline Mesaticephalic & $5(16.6 \%)$ & 3 & 2 & $4.33 \pm 2.67$ \\
\hline Brachycephalic & $2(6.6 \%)$ & 2 & 0 & $1.5 \pm 0.5$ \\
\hline
\end{tabular}

\section{DISCUSSION}

The literature available on sutural bones explains that it is one of the common variants of human anatomy and the presence of which is not rare, but the population based variations in their number and location need to be paid attention to.

In the present study of the East Indian population, the prevalence of sutural bones was observed to be in
$43.33 \%$ of the skulls studied. This value is much lower than that reported by Brothwell [13], who studied the prevalence of sutural bones in different Chinese, German, Australian, Romano-British, Melanesian, Lachish and Anglo-Saxon populations (Table VI). The present study value was less than that reported by Cirpan et al. $[14,15]$ in the West Anatolian population. Nevertheless, as we approach the East India population via Nepal, it can be observed that there is a continuous decrease in the incidence of sutural bones as the reported value of 
$88.57 \%$ of the Central Nepal population [16] is followed by a value of $68.75 \%$ in Eastern Nepal reported by Sah et al. [17] in 2017. This variation can be explained by the variable genetic predispositions among different races as proposed by Berry and Berry [18] and Hanihara and Ishida [19].

\begin{tabular}{lc}
$\begin{array}{l}\text { Table VI. Incidence of sutural bones in different populations of world } \\
\text { Tabela VI. Występowanie kości wstawnych w różnych populacjach świata }\end{array}$ \\
\hline \multicolumn{1}{c}{ Population } & Incidence (\%) \\
\hline Chinese $^{*}$ & 80.32 \\
German* $^{*}$ & 75 \\
Australian* & 72.58 \\
Iron Age/Romano-British* & 71.03 \\
Melanesian* & 64.15 \\
Lachish* $^{*}$ & 63.41 \\
Anglo-Saxon* & 55.56 \\
Malaysians [21] & 24 \\
West Anatolian [14,15] & 59.3 \\
Nepalese (Eastern Nepal) [17] & 68.75 \\
Central Nepalese [16] & 88.57
\end{tabular}

*According Brothwell [13]

Then again as we go south in India, it can be observed that there is a continuous increase in the incidence of sutural bones as suggested by the reported values of $73.1 \%$ and $81.89 \%$ by Murlimanju et al. [20] and Shantharam and Manjunath [2] in the South Indian population.

The present study of the prevalence of sutural bones was found to be comparable with the values reported by Patel et al. [1] in the Western Indian population of Gujrat and also in the South Indian population of Karnataka (Table VII). The prevalence of sutural bones reported by Khan et al. [21] in the Malaysian population was the only one found to be lower than that of the present study values (Table VI).

\begin{tabular}{lc}
$\begin{array}{l}\text { Table VII. Incidence of sutural bones in different Indian populations } \\
\text { Tabela VII. Występowanie kości wstawnych w różnych populacjach indyj- } \\
\text { skich }\end{array}$ \\
\hline \multicolumn{1}{c}{ Population } & Incidence (\%) \\
\hline Coastal South Indian [20] & 73.1 \\
South Indian [2] & 81.89 \\
South Indian (Tumkur, Karnataka) & 43.52 \\
South Indian (Banglore, Karnataka) & 52.22 \\
West Indian (Gujrat) & 44.04 \\
East Indian (Bihar), present study & 43.33 \\
\hline
\end{tabular}

${ }^{* *}$ According Patel et al. [1]

The regional distribution of sutural bones in skulls was observed to be the highest around the lambdoid suture $(61.2 \%)$ in the present study. This finding was comparable to the values reported by Gümüsburun et al. [22] in the Turkish population $(61.89 \%)$, Sah et al. [17] in
Eastern Nepal (63.63\%) and Basnet et al. [16] in the Central Nepalese population $(61.43 \%)$. The findings of the LS being the most common location for sutural bones concurs with the findings reported by Pal et al. [23] in the Gujrati population, Gopinathan et al. [24] in the North Indian population, Shantharam and Manjunath [2], Murlimanju et al. [20], Shivaleela et al. [26], and Showri and Suma [25] in different regions of the South Indian population and Kumar and Nagar [31] in the Central Indian population but the prevalence is much lower than that observed in the present study and that reported by Gümüsburun et al. [22], Sah et al. [17] and Basnet et al. [16] (Table VIII).

After the LS, the second highest incidence of sutural bones with values of $10.6 \%$ were seen around the coronal sutures. The incidental value of sutural bones at the CS concurred with the reported value by Shantharam and Manjunath [2] in the South Indian population, while others reported values much lower than the present study and none had the CS as the second most common site for sutural bones (Table VIII).

The value of incidence for sutural bones was observed to be $8.2 \%$ at the lambda or posterior fontanelle in the present study; this was comparable to the value reported by Khan et al. [21] in the Malaysian population and Shivaleela et al. [26] in the South Indian population. Kumar and Nagar [31] was the only study to report a lower incidence of sutural bones at the lambda than that of the present study, while other studies by Pal et al. [23] in the Gujrati population, Shantharam and Manjunath [2] in the South Indian population observed a higher percentage of the common variant in study at the lambda (Table VIII).

The epipteric bone incidence of $7.05 \%$ in the present study population was comparable to the study values of Pal et al. [23] in the Gujrati population and that of Gopinathan et al. [24] in the North Indian population. The incidence of sutural bones at the pterion was observed to be much higher in the Nepalese population as reported by both Sah et al. [17] in East Nepal and Basnet et al. [16] in Central Nepal, the same was observed in the South Indian population reported by Shantharam and Manjunath [2] and Murlimanju et al. [20]. Nonetheless, the values of epipteric bones reported in the South Indian population by Shivaleela et al. [26] and Showri and Suma [25] are much lower than that of the present study values or other South Indian population studies (Table VIII). In the present study only unilateral occurrence of the epipteric bone was observed as reported by Murlimanju et al. [20], though bilateral occurrences had been reported by Basnet et al. [16]. Ersoy et al. [27] mentions that knowledge of the existence of epipteric bones is essential for neurosurgeons as their presence can lead to complications while making burr holes for operating on intracranial tumors [27].

The incidence of OM sutural bones in the present study was observed to be at $5.88 \%$, comparable to the values presented by Kumar and Nagar [31] in the Central Indian population, Pal et al. [23] in the Gujrati population and by Gopinathan et al. [24] in the North Indian 
Table VIII. Incidence of sutural bones in different regions of skulls among various populations around the world (\%) Tabela VIII. Występowanie kości wstawnych w czaszkach różnych populacji całego świata (\%)

\begin{tabular}{|c|c|c|c|c|c|c|c|c|c|c|}
\hline Population Groups & LS & SS & SqS & PM & OM & CS & Asterion & $\begin{array}{l}\text { Epipteric } \\
\text { bone }\end{array}$ & Bregma & Lambda \\
\hline Turkish [22] & 61.89 & 1.65 & - & 7.92 & 0.99 & 2.97 & 15.2 & 9.92 & 0.66 & 10.9 \\
\hline Malaysian [21] & 4 & 8 & 4 & 4 & 4 & 8 & 0 & 0 & 0 & 8 \\
\hline $\begin{array}{l}\text { Nepalese (Eastern Nepal) } \\
\text { [17] }\end{array}$ & 63.63 & 3.63 & - & - & - & 0 & 20 & 12.72 & 0 & - \\
\hline Central Nepalese [16] & 61.43 & 7.14 & 7.14 & 41.43 & 27.14 & 4.28 & 24.29 & 25.71 & 0 & 11.43 \\
\hline Gujrati [23] & 37.4 & 1.05 & - & 11.26 & 6.68 & 0 & 13.95 & 7.74 & 0 & 20.07 \\
\hline North Indian [24] & 30.3 & 1.12 & - & 11.24 & 5.62 & 3.37 & 12.4 & 6.74 & 0 & 12.4 \\
\hline South Indian [28] & 30.6 & 5.35 & - & 15.38 & 7.35 & 5.18 & 14.88 & 11.54 & 0.67 & 22.41 \\
\hline Coastal South Indian [20] & 56.4 & 1.3 & - & - & - & 1.3 & 17.9 & 11.5 & 0 & - \\
\hline South Indian [26] & 33.33 & 0.92 & - & 3.7 & 0 & 2.78 & 11.11 & 1.85 & 0 & 8.33 \\
\hline South Indian [25] & 45.45 & 4.54 & 2.27 & 8.33 & 2.27 & 6.06 & 5.3 & 1.51 & 0 & 13.63 \\
\hline Central Indian [31] & 44 & 0 & - & - & 6 & - & 6 & 2 & 0 & 6 \\
\hline South Indian [2] & 48.18 & 3.64 & - & 35.45 & 13.64 & 10 & 38.18 & 20.91 & 0 & 22.73 \\
\hline East Indian, present study & 61.2 & 0 & 2.35 & 2.35 & 5.88 & 10.6 & 2.35 & 7.05 & 0 & 8.2 \\
\hline
\end{tabular}

LS - lambdoid sutures; SS - sagittal suture; SqS - squamous suture; PM - parietomastoid; OM - occipitomastoid; CS - coronal suture.

population. These values were higher than those reported by Gümüsburun et al. [22] in the Turkish population and Khan et al. [21] in the Malaysian population and lower than those reported by Basnet et al. [16] and Shantharam and Manjunath [2].

Table III shows that the incidence of sutural bones at the asterion, $\mathrm{SqS}$ and $\mathrm{PM}$ in the present study was observed to be the same, at $2.35 \%$. On comparing these values with the available literature presented in Table VIII, it can be deduced that the incidence of sutural bones at the asterion and PM in the present study population was lower than all the compared populations, with the exception of the Malaysian population with no reported asterion ossicle. Sutural bones at the squamous suture, though more rarely observed, was seen to be reported with a higher incidence in the Malaysian population by Khan et al. [21] and in the Central Nepalese population by Basnet et al. [16]. The present study value for the $\mathrm{SqS}$ was comparable with that reported by Showri and Suma [25] in the South Indian population.

The dominant shape of the head in the present study population was the dolichocephalic head, observed in
$46.6 \%$ of the examined skulls. This value was similar to that reported by Basnet et al. [16] in the Central Nepalese population, while Lobo et al. [29] reported the brachycephalic type of head to be more common (38.2\%) in the Gurung community of Nepal. Anjum and Kanwal [11] and Kumar and Nagar [31] reported mesaticephalic skulls as the dominant head shape in South Punjab and Indian population, Akinbami [30] concurred these findings in the Nigerian population. Thus, the head shape may vary among various geographic and ethnic groups.

\section{CONCLUSIONS}

The value of the incidence of sutural bones in $43 \%$ of the studied skulls may vary with a large sample size. Though the current study reports fewer sutural bones than in many of the previous works, given the high population density of the East Indian states, these presented mean values require special attention particularly by radiologists and neurosurgeons performing different clinical procedures such as burr holes or radiological studies.

\section{Author's contribution}

Study design - R. K. Narayan

Data collection - S. Kumari

Data interpretation - S. Kumari

Statistical analysis - R. K. Narayan

Manuscript preparation - M. Verma

Literature research - R. K. Narayan 


\section{REFERENCES}

1. Patel D., Chauhan K., Patil D. Morphological Study of Wormian Bones in Dried Human Skulls. Natl. J. Med. Res. 2015; 5(3): 222-225.

2. Shantharam V., Manjunath K.Y. Occurrence of Sutural Bones in Adult Human Skulls. NJBMS 2017; 7(4): 201-208.

3. Ogle R.C., Tholpady S.S., McGlynn K.A., Ogle R.A. Regulation of crania suture morphogenesis. Cells Tissues Organs 2004; 176(1-3): 54-66.

4. Jeanty P., Silva S.R., Turner C. Prenatal diagnosis of wormian bones. J. Ultrasound Med. 2000; 19(12): 863-869, doi: 10.7863/jum.2000.19.12.863.

5. Barberini F., Bruner E., Cartolari R., Franchitto G., Heyn R., Ricci F., Manzi G. An unusually-wide human bregmatic Wormian bone: anatomy, tomographic description, and possible significance. Surg. Radiol. Anat. 2008; 30(8): 683-687, doi: 10.1007/s00276-008-0371-0.

6. Hess L. Ossicula wormiana. Hum. Biol. 1946; 18: 61-80.

7. Hauser G., De Stefano G.F. Epigenetic variants of the human skull. E. Schweizerbart'sche Verlagsbuchhandlung: Stuttgart 1989, p. 301.

8. Grüneberg H. The pathology of development: A study of inherited skeletal disorders in animals. Blackwell: Oxford 1963, p. 108.

9. Kaplan S.B., Kemp S.S., Oh K.S. Radiographic manifestations of congenita anomalies of the skull. Radiol. Clin. North Am. 1991; 29(2): 195-218.

10. Pryles C.V., Khan A.J. Wormian bones: a marker of CNS abnormality? Am. J. Dis. Child. 1979; 133(4): 380-382.

11. Anjum M.I., Kanwal S. A Craniometric Study of Adult Dry Skulls in South Punjab. Pak. J. Med. Health Sci. 2016; 10(1): 244-246.

12. Garson J.G. The international agreement on the classification and nomenclature of the cephalic index. The Journal of the Anthropalogical Institute of Great Britain and Ireland 1887; 16: 17-20.

13. Brothwell D.R. Digging up bones: the excavation, treatment, and study of human skeletal remains. British Museum 1963, p. 13-21.

14. Cirpan S., Aksu F., Mas N. Inca bone in human skulls of the West Anatolian population. Int. J. Morphol. 2014; 32(1): 275-278.

15. Cirpan S., Aksu F., Mas N. The incidence and topographic distribution of sutures including Wormian bones in human skulls. J. Craniofac. Surg. 2015; 26(5): 1687-1690, doi: 10.1097/SCS.0000000000001933.

16. Basnet L.M., Shrestha S., Sapkota S. Prevalence of wormian bones in dried adult human skulls: an osteo-morphometric study in Nepal. Anat. Sci. Int. 2019: 94(1): 101-109, doi: 10.1007/s12565-018-0454-x.
17. Sah S.K., Chaudhary D., Pandey N. Study of Metopism and Wormian Bones in Dry Skulls of Human Cadavers in Nepal. Int. J. Anat. Res. 2017; 5(1): 3443-3446, doi: 10.16965/ijar.2016.499.

18. Berry A.C., Berry R.J. Epigenetic variation in the human cranium. J. Anat. 1967; 101(Pt 2): 361-379.

19. Hanihara T., Ishida $H$. Frequency variations of discrete cranial traits in major human populations. I. Supernumerary ossicle variations. J. Anat. 2001; 198(Pt6): 689-706, doi: 10.1046/j.1469-7580.2001.19860689.x.

20. Murlimanju B.V., Prabhu L.V., Ashraf C.M., Kumar C.G., Rai R., Maheshwari C. Morphological and topographical study of Wormian bones in cadaver dry skulls. J. Morphol. Sci. 2011; 28(3): 176-179.

21. Khan A.A., Asari M.A., Hassan A. Unusual presence of Wormian (sutural) bones in human skulls. Folia Morphol. 2011; 70(4): 291-294.

22. Gümüsburun E., Sevim A., Katkici U., Adigüzel E., Güleç E. A study of sutural bones in Anatolian-Ottoman skulls. Int. J. Anthrop. 1997; 12(2): 43-48. 23. Pal G.P., Tamankar B.P., Routal R.V., Bhagwat S.S. The ossification of the membraneous part of the squamous occipital bone in man. J. Anat. 1984; 138(Pt2): 259-266.

24. Gopinathan K., Dhall U., Chhabra S: Sutural bones in the north Indian population. J. Anat. Soc. India 1998; 47(2): 91-96.

25. Showri R., Suma M.P. Study of Wormian bones in adult human skulls. IOSR-JDMS 2016; 15(12): 54-60, doi: 10.9790/0853-1512055460.

26. Shivaleela C., Kumar G.V., Malipatil S.B., Sandhya K. Morphological Study of Wormian Bones in Dried Human Skulls. Res. J. Pharm. Biol. Chem. Sci. 2013; 4(2): 584-589.

27. Ersoy M., Evliyaoglu C., Bozkurt M.C., Konuskan B., Tekdemir I., Keskil İ.S. Epipteric bones in the pterion may be a surgical pitfall. Minim. Invasive Neurosurg. 2003; 46(06): 363-365, doi: 10.1055/s-2003-812434.

28. Manjunath K. Y., Balasubramanyam V. Incidence of sutural bones in south Indian skulls. Anatomica Karnataka 2004; 1(5): 49-54.

29. Lobo S.W., Chandrasekhar T.S., Kumar S. Cephalic index of Gurung community of Nepal - an anthropometric study. Kathmandu Univ. Med. J. 2005; 3(3): 263-265.

30. Akinbami B.O. Measurement of Cephalic Indices in Older Children and Adolescents of a Nigerian Population. Biomed Res. Int. 2014: 527473, doi: $10.1155 / 2014 / 527473$

31. Kumar A., Nagar M. Morphometric estimation of cephalic index in north Indian population: craniometrics study. Int. J. Sci. Res. 2015; 4(4): 1976-1982. 